\title{
METODE BLENDED LEARNING DALAM MENINGKATKAN MINAT BELAJAR MAHASISWA MELALUI MATA KULIAH PSIKOLOGI PENDIDIKAN DI MASA PANDEMI COVID-19
}

\author{
Irma Noervadila $^{1}$, Dyan Yuliana ${ }^{2}$, Yesi Puspitasari ${ }^{3}$ \\ ${ }^{1,2,3}$ STKIP PGRI SITUBONDO \\ Email: noervadilairma@gmail.com
}

Received: June 10, 2020 Revised: June 13, 2020 Accepted: June 15, 2020

\begin{abstract}
ABSTRAK
Penelitian ini merupakan penelitian yang dilakukan dalam kondisi pandemi, yang sedang melanda dunia termasuk Indonesia saat ini, mengakibatkan interaksi tatap muka di kelas antara dosen dan mahasiswa tidak mungkin untuk dilakukan. Oleh karena itu pembelajaran digital menjadi alternatif yang penting untuk mengganti tatap muka dikellas. Namun dalam realitas sesungguhnya, banyak persoalan ketidaksiapan yang ditemukan untuk melaksanakan pembelajaran digital baik terkait dengan sarana prasarana maupun mahasiswa. Salah satu cara yang paling memungkinkan untuk mengatasi hal tersebut adalah melalui metode pembelajaran blended learning untuk meningkatkan minat belajar mahasiswa melalui mata kuliah Psikologi Pendidikan. Tujuan pokok penelitian ini adalah untuk mengetahui apakah metode pembelajaran blended learning dapat meningkatkan minat belajar mahasiswa. Metode yang digunakan dalam penelitian ini menggunakan kajian literatur kepustakaan di mana peneliti menganalisis berbagai penelitian yang relevan dengan metode blended learning untuk meningkatkan minat belajar mahasiswa. Penyajian data dilakukan dengan teknik deskriptif yaitu menggambarkan metode pembelajaran blended learning untuk meningkatkan minat belajar mahasiswa. Hasil penelitian menunjukkan bahwa metode blended learning dapat meningkatkan minat belajar mahasiswa.
\end{abstract}

Kata kunci : Blended Learning, Psikologi Pendidikan

\begin{abstract}
The pandemic condition, which is currently sweeping the world including Indonesia, makes face-to-face interactions in class between teachers and students impossible to do. Therefore, digital learning is an important alternative to replace face-to-face classrooms. But in reality, many unpreparedness issues are found to carry out digital learning both related to infrastructure and students. One of the most possible ways to overcome this is through the adaptation of blended learning in the face of the new normal, especially in sociology learning. The main objective of this study is to determine the adaptation of sociology learning by blended learning and Indonesian education policies in preventing Covid-19. The method used in this study is a literature review where the researcher analyzed various studies relevant to the adaptation of Psycological learning. The presentation of the data is carried out using descriptive techniques, which describe the blended learning method that occures in the face of the new normal period. The results show that
\end{abstract}

Keywords: blended learning, interest to learn, educational psychology 


\section{PENDAHULUAN}

Dalam penelitian ini, pembahasan blended learning dikhususkan pada adaptasi dan penggunaannya dalam pembelajaran Psikologi Pendidikan. Psikologi Pendidikan merupakan ilmu yang menerapkan teori-teori dan konsep psikologi untuk memahami meningkatkan pembelajaran dan pengajaran. Dengan mempelajari Psikologi Pendidikan bisa memahami kondisi psikologi mahasiswa. Pembelajaran Psikologi Pendidikan berupaya menerapkan teori-teori dan konsep psikologi untuk memahami dan meningkatkan pembelajaran dan pengajaran di lingkungan pendidikan formal. Sederhananya, psikologi pendidikan berkaitan dengan studi bagaimana mahamahasiswa belajar (baik anak, remaja, maupun dewasa) dan bagaimana dengan ilmu psikologi dosen dapat membantu mereka untuk belajar dengan efektif.

Sebenarnya, pembelajaran dengan model blended mampu menguatkan kemampuan belajar mandiri pada mahamahasiswa, ini berdasarkan penelitian yang dilakukan sebelum masa pandemic covid-19. Pembelajaran blended memfasilitasi Dosen dan mahamahasiswa untuk selalu terhubung kapanpun dan dimanapun. Berdasarkan dua penelitian ini dapat diketahui bahwa pembelajaran dengan model blended learning relevan untuk diterapkan di masa pandemi ini. Peneliti memfokuskan penelitian pada model mengajar dengan blended learning oleh dosen dalam mata kuliah psikologi pendidikan di lingkungan STKIP PGRI Situbondo.

Berdasarkan latar belakang di atas, maka rumusan masalah adalah apakah metode blended learning dalam meningkatkan minat belajar mahamahasiswa melalui mata kuliah psikologi pendidikan?

\section{METODE PENELITIAN}

Metode yang digunakan dalam penelitian ini adalah kajian literatur kepustakaan di mana peneliti menganalisis berbagai artikel penelitian yang relevan dengan metode pembelajaran blended learning dalam pembelajaran Psikologi pendidikandan kebijakan pendidikan Indonesia dalam mencegah covid 19. Penyajian temuan dilakukan dengan teknik deskriptif, yaitu dengan menggambarkan adaptasi pembelajaran Psikologi pendidikan secara blended learning dalam menghadapi masa new normal.

Jenis penelitian yang temuan-temuannya tidak diperoleh melalui prosedur statistik atau bentuk hitungan lainnya. Berusaha memahami dan menafsirkan makna suatu peristiwa interaksi tingkah laku manusia dalam situasi tertentu menurut perspektif peneliti sendiri. Dilakukan dalam situasi yang wajar (natural setting). Metode kualitatif 
lebih berdasarkan pada sifat fenomenologis yang mengutamakan penghayatan (Gunawan, 2013).

\section{HASIL DAN PEMBAHASAN}

Voos dalam Perez, et al. (2010) menyatakan bahwa blended learning merupakan perkembangan terbaru dalam pendidikan yang menggabungkan kelas tatap muka dengan modul e-learning, yang memungkinkan untuk menikmati keuntungan dari kedua metode pengajaran. Keuntungan lain yang didapat seperti fleksibilitas yang lebih besar dan pengurangan biaya dibandingkan dengan kelas tradisional, terutama ketika sejumlah besar mahasiswa harus diajar. Jenis pembelajaran ini menghadirkan serangkaian keunggulan dibandingkan penggunaan eksklusif pembelajaran berbasis teknologi.

Studi sebelumnya telah melaporkan bahwa kualitas dan hasil belajar dipengaruhi ketika mahasiswa hanya menggunakan metode seperti itu, mungkin karena: a) kurangnya interaksi dengan guru dan mahasiswa lainnya, b) penundaan dalam pembelajaran asinkron, c) berkurangnya motivasi untuk membaca materi pembelajaran online. Blended learning mungkin mampu meningkatkan, memperluas bahkan mengubah perspektif Ilmu Pendidikan.

Studi lain dilakukan oleh Bonk et al. (2002) dalam kursus tingkat tinggi di militer yang bertujuan untuk memahami bagaimana pendekatan campuran memengaruhi pengembangan profesional mahasiswa dalam kursus militer. Para peneliti ini tidak merancang kursus pembelajaran campuran secara lengkap namun hanya upaya untuk mendukung kursus pembelajaran online dengan sesi tatap muka di waktu yang berbeda. Mereka mengaplikasikan pembelajaran berbasis internet asinkron pada fase pertama, pembelajaran sinkron dalam alat obrolan kolaboratif virtual dan pembelajaran tatap muka pada fase ketiga. Selain itu mereka melakukan wawancara dengan mahasiswa, instruktur, penasihat pendidikan tentang keuntungan dan kerugian yang dirasakan dari sistem tersebut. Hasil keseluruhan menunjukkan bahwa meskipun pembelajaran online lebih disukai karena menyenangkan dan fleksibel; namun kegiatan pembelajaran paling banyak terjadi pada fase tatap muka.

George-Walkera dan Keeffeb (2010) mengkaji tentang determinasi diri dalam blended learning pada mahamahasiswa dan pendidikan tinggi. Penelitian ini menyarankan bahwa pendidikan tinggi diharapkan menemukan model pembelajaran yang lebih efektif dan fleksibel dan memberikan semua mahasiswa akses ke pengalaman belajar yang berkualitas, tetapi juga memenuhi keharusan kelembagaan untuk efisiensi dan 
akuntabilitas.

Penelitian ini mengusulkan blended learning sebagai salah satu solusi untuk memenuhi kebutuhan belajar mahasiswa dan pendidikan tinggi karena blended learning merupakan strategi yang efektif dan berisiko rendah. Mahasiswa yang memiliki waktu sedikit untuk belajar dan harus lebih komitmen terhadap keluarga, penghasilan, kesehatan, olahraga, teknologi, dan minat lain menuntut serangkaian jalur akses untuk belajar dan informasi. Pada saat yang sama, universitas terikat oleh standar komunitas dan profesional termasuk integritas akademik, efisiensi organisasi, retensi mahasiswa dan tuntutan masyarakat akan pekerja yang mengerti teknologi dan berpengetahuan luas.

McCarthy (2010) mengeksplorasi pencampuran lingkungan belajar virtual dan fisik untuk meningkatkan pengalaman tahun pertama dengan membaurkan mahasiswa ke dalam budaya universitas melalui interaksi sosial dan akademik antar sejawat. Dia melaporkan kemajuan yang dibuat oleh mahamahasiswa dari tahun 2008 hingga tahun 2009 saat menggunakan platform akademik yang ada. Partisipan terlibat secara aktif dengan rekan-rekan mereka melalui forum online di dalam situs Facebook, selain mekanisme pengajaran tradisional seperti ceramah dan tutorial. Mahasiswa diminta untuk mengirimkan pekerjaan secara online ke Facebook dan memberikan kritik atas pengiriman rekan. Diskusi yang dihasilkan kemudian dipindahkan ke kelas fisik dengan tujuan membangun hubungan yang bermakna antara teman sebaya berdasarkan koneksi online embrionik. Proses evaluasi melibatkan kuesioner pra dan pasca semester, umpan balik mingguan dari mahasiswa dan refleksi spesifik proyek pada akhir semester.

Partisipan dalam penelitian McCarthy (2010) ini termasuk dalam Generasi-Y atau 'digital asli' yang menghabiskan seluruh hidup mereka dengan dikelilingi dan menggunakan komputer, videogame, pemutar musik digital, kamera video, telepon seluler, dan semua mainan dan alat lain dari zaman digital. Dia berpendapat bahwa budaya digital dan lingkungan di mana penduduk asli telah tumbuh telah mengubah cara mereka berpikir memproses informasi secara fundamental yang berbeda dari pendahulunya. Dengan demikian budaya digital di mana penduduk asli digital telah tumbuh telah memengaruhi preferensi dan keterampilan mereka dalam sejumlah bidang utama yang berkaitan dengan pendidikan.

Literatur pendukung juga menyatakan bahwa penduduk asli digital lebih suka menerima informasi dengan cepat; mahir memproses informasi dengan cepat; lebih suka akses multi-tasking dan nonlinear ke informasi; memiliki toleransi yang rendah untuk kuliah; lebih suka belajar aktif daripada pasif, dan sangat bergantung pada teknologi 
komunikasi untuk mengakses informasi dan untuk melakukan interaksi sosial dan profesional.

Halverson, et al. (2012) dalam kajiannya tentang dampak pengetahuan dan tren publikasi dalam blended learning menyatakan bahwa artikel dalam hal blended learning telah banyak sekali dipublikasi dan dikutip. Kaur (2012) juga menyatakan bahwa saat ini tren e-learning meningkat dari hari ke hari dan salah satu alat untuk menerapkan konsep ini adalah melalui blended learning.

Penelitian ini juga mengungkapkan metode yang digunakan dalam blended learning seperti metode pembelajaran sinkron dan metode pembelajaran asinkron, yang akan membantu pembaca untuk memilih metode pembelajaran terbaik. Selain itu, makalah ini juga mengungkapkan dimensi pendekatan blended learning yaitu blending offline dan online learning, blending sendiri dan live blending, pembelajaran kolaboratif, dan memadukan pembelajaran terstruktur dan tidak terstruktur.

Norberg, et al. (2011) berupaya menguraikan strategi berbasis waktu untuk blended learning dengan membingkai peluang belajar mahasiswa dalam modalitas yang sinkron dan asinkron. Makalah ini mendekonstruksi komponen yang berkembang dari blended learning untuk mengidentifikasi perubahan yang disebabkan oleh teknologi digital untuk meningkatkan lingkungan belajar mengajar. Hasil penelitian ini menunjukkan bahwa blended learning dapat ditelusuri kembali ke awal abad pertengahan ketika materi cetak memberikan kesempatan belajar asinkron pertama. Namun, digitalisasi lingkungan belajar kontemporer menghasilkan penekanan pada ruang pengajaran dan pembelajaran. Ketika waktu menjadi konstruksi pengorganisasian utama untuk pendidikan dalam lingkungan yang didukung teknologi, kemungkinan muncul lima komponen campuran: migrasi, dukungan, lokasi, pemberdayaan pelajar, dan aliran. Fokus membuat konsep pembelajaran campuran sebagai kombinasi dari media modern, mode komunikasi, waktu dan tempat dalam jenis baru sintesis pembelajaran di tempat kelas tradisional dan teknologi dengan guru yang melayani sebagai fasilitator dari proses pembelajaran kolektif.

Pengaruh Blended Learning Sjukur (2012) mengkaji tentang pengaruh blended learning terhadap motivasi dan hasil belajar mahasiswa SMK. Dia menemukan ada perbedaan yang signifikan antara mahasiswa yang belajar secara blended dengan mahasiswa yang belajar tanpa blended dengan perbedaan nilai sig. 0,012 dengan ratarata 4, 74 dan perbedaan hasil belajar dengan nilai sig. 0,000 dengan rata-rata 13,39. Juga ada peningkatan motivasi belajar mahasiswa yang menerapkan pembelajaran blended 
learning dengan nilai sig. 0,000. Francis \& Shannon (2013) mengkaji tentang keterlibatan mahasiswa dalam blended learning dan hubungannya dengan hasil belajar. Menurut mereka, blended learning sangat sesuai digunakan untuk meningkatkan pembelajaran di bidang teknik (arsitektur), desain dan arsitektur karena merupakan perpaduan sempurna dari modul online yang dipilih dengan cermat dengan instruksi tatap muka. Penelitian Ini menunjukkan bahwa mahasiswa yang tidak terlibat dengan blended learning secara akademis dirugikan.

Menurut Dykman (Francis \& Shannon, 2013), waktu dan sumber daya yang intensif sangat diperlukan untuk mempersiapkan dan mendukung elemen online untuk pembelajaran yang sukses dalam mode blended learning. Dalam akademisi teknik dan arsitektur, pengadopsi awal telah termotivasi untuk mengeksplorasi kemungkinan untuk integrasi pembelajaran dan pengajaran tatap muka dan online untuk mengejar manfaat hasil pembelajaran yang diperoleh dari mode pembelajaran dan pengajaran ini. Salah satu manfaat dari blended learning adalah kesempatan untuk meningkatkan keterlibatan mahasiswa - menggeser dan memperkuat struktur peran mahasiswa dalam pendidikan mereka sendiri sebagai pemelajar aktif.

Blended learning memiliki kapasitas untuk memanfaatkan ekspektasi mahamahasiswa bahwa cara penyampaian akan paralel dengan dunia luar universitas mereka yang ada dalam 'format' terpadu ini. Blended learning membutuhkan perubahan spektrum di semua aspek pendidikan, termasuk dalam struktur kurikulum. Ada kesenjangan antara ekspektasi mahasiswa asli digital dan kapasitas yang sampai sekarang telah ditunjukkan staf untuk mengadopsi blended learning dan menyesuaikan kurikulum. Saat ini, adopsi sangat tergantung pada staf pengajar individu - mereka yang ingin mengadopsi, yang meneliti bagaimana beradaptasi, dan yang kemudian menyelidiki dan menyediakan alat untuk melakukan ini. Namun, fokus kelembagaan sering tetap pada alokasi sumber daya untuk menyediakan 'alat' dan 'pelatihan untuk alat', namun mengalokasikan sumber daya yang kurang untuk mendukung pengembangan pendekatan pedagogis dalam mengembangkan blended learning and teaching.

So dan Bonk (2013) dalam kajiannya tentang peran blended learning dalam kolaborasi yang dibantu oleh komputer menemukan bahwa blended learning telah meningkatkan minat dan perhatian partisipan mereka. Tetapi peningkatan minat dan perhatian ini sangat bergantung pada proporsi yang tepat antara pembelajaran online dan offline.

Anderson (2003) menunjukkan bahwa "mendapatkan campuran yang tepat 
melibatkan serangkaian pertukaran, dan mengetahui bagaimana satu jenis interaksi dapat secara efektif menggantikan yang lain, memberikan keterampilan pengambilan keputusan penting dalam basis pengetahuan pendidikan jarak jauh".

Lin dan Wang (2013) meneliti tentang bukti niat untuk mengadopsi e-learning system dalam blended learning yang bertujuan menyelidiki hubungan antara hal yang dirasakan dan faktor sistem yang dapat memotivasi peserta didik untuk terus menggunakan sistem e-learning dalam instruksi pembelajaran campuran. Hasil penelitian mengungkapkan bahwa kualitas informasi dan tugas-teknologi berpengaruh terhadap penerimaan sistem. Kegunaan yang dirasakan dan kepuasan terhadap sistem memiliki dampak besar pada niat keberlanjutan penggunaan.

Mean (2013) dalam penelitiannya tentang bukti empirik efektifitas blended learning menyatakan bahwa meningkatnya kemampuan penggunaan aplikasi berbasis web dan teknologi kolaborasi dan munculnya model pembelajaran campuran yang menggabungkan pengajaran berbasis web dan kelas tatap muka telah meningkatkan harapan untuk efektivitas pembelajaran online. Hasil meta-analisis ini menemukan bahwa, rata-rata mahasiswa dalam kondisi pembelajaran online berkinerja lebih baik daripada mereka yang menerima instruksi hanya secara tatap muka. Kesimpulan studi ini menemukan bahwa menggunakan blended learning juga cenderung melibatkan waktu belajar tambahan, sumber daya pengajaran, dan elemen pembelajaran yang mendorong interaksi di antara peserta didik.

\section{KESIMPULAN}

Simpulan Metode blended learning adalah metode belajar masa kini dan masa depan pendidikan. Ini adalah salah satu fitur utama dari paradigma pendidikan modern, dengan blended learning membantu mempersonalisasi pendidikan, dan memungkinkan mahasiswa untuk menjadi lebih produktif tentunya memiliki minat belajar yang tinggi. Metode pembelajaran blended learning dalam menghadapi masa newnormal dapat meningkatkan minat belajar mahasiswa melalui mata kuliah Psikologi Pendidikan.

Saran Pendidik atau calon pendidik hendaknya memiliki kemampuan teknologi agar adaptasi pembelajaran sosiologi secara blended learning berjalan dengan baik. 


\section{DAFTAR PUSTAKA}

Alebaikan, R. \& Troudi, S. (2003). Blended learning in Saudi universities: challenges and perspectives." ALT-J, 18(1) (2010), 49-59, DOI: 10.1080/09687761003657614. Anderson, T. (2003).

Getting the Mix Right Again: An Updated and Theoretical Rationale for Interaction. The International Review of Research in Open and Distributed Learning, 4(2), 1-14, DOI: https://doi.org/10.19173/irrodl.v4i2.149.

Azizan, F. Z. (2010). Blended learning in higher education institution in Malaysia. In Proceedings of regional conference on knowledge integration in ICT, 10, 454-466, URL: http://library.oum.edu. my/oumlib/node/4334.

Bonk, C. J., Olson, T. M., Wisher, R. A., \& Orvis, K. L. (2002). Learning from focus groups: An examination of blended learning. International Journal of E-Learning \& Distance Education/ Revue internationale du e-learning et la formation à distance, 17(3), 97-118.

Drysdale, J. S., Graham, C. R., Spring, K. J., \& Halverson, L. R. (2013). An analysis of research trends in dissertations and theses studying blended learning. The Internet and Higher Education, 17, 90-100, http://dx.doi.org/10.1016/j. iheduc.2012.11.003.

Francis, R., \& Shannon, S. J. (2013). Engaging with blended learning to improve students' learning outcomes. European Journal of Engineering Education, 38(4), 359-369, DOI:10.1080/03043797.2013.766679.

Garrison, D. R., \& Vaughan, N. D. (2013). Institutional change and leadership associated with blended learning innovation: Two case studies. The internet and higher education, 18, 24-28, DOI: 10.1016/j.iheduc.2012.09.001.

George- Walker, L. D., \& Keeffe, M. (2010). Self- determined blended learning: a case study of blended learning design. Higher Education Research \& Development, 29(1), 1-13, DOI: https://doi.org/10.1080/07294360903277380.

Güzer, B., \& Caner, H. (2014). The past, present and future of blended learning: an in depth analysis of literature. Procedia-social and behavioral sciences, 116, 45964603, DOI: https://doi. org/10.1016/j.sbspro.2014.01.992.

Halverson, L. R., Graham, C. R., Spring, K. J., \& Drysdale, J. S. (2012). An analysis of high impact scholarship and publication trends in blended learning. Distance Education, 33(3), 381-413, DOI: https://doi.org/10.1080/01587919.2012.723166.

I Gunawan.(2013).Metode Penelitian Kualitatif - Jakarta: Bumi Aksara, academia.edu 
Kaur, M. (2013). Blended learning-its challenges and future. Procedia-Social and Behavioral Sciences, 93, 612-617, DOI: 10.1016/j.sbspro.2013.09.248.

Lin,W. S., \& Wang, C. H. (2012). Antecedences to continued intentions of adopting elearning system in blended learning instruction: A contingency framework based on models of information system success and tasktechnology fit. Computers \& Education, 58(1), 88-99, DOI: http://dx.doi.org/10.1016/j. compedu.2011.07.008. López-Pérez, M. V.,

Pérez-López, M. C., \& Rodríguez- PERSPEKTIF Ilmu Pendidikan - Vol. 34 No. 2 Oktober 202091 Adaptasi Pembelajaran Sosiologi... Ariza, L. (2011). Blended learning in higher education: Students' perceptions and their relation to outcomes. Computers \& education, 56(3), 818-826, DOI: http://dx.doi.org/10.1016/j. compedu.2010.10.023.

McCarthy, J. (2010). Blended learning environments: Using social networking sites to enhance the first year experience. Australasian Journal of Educational Technology, 26(6), 729-740, DOI: https://doi.org/10.14742/ajet.1039.

Means, B., Toyama, Y., Murphy, R., \& Baki, M. (2013). The effectiveness of online and blended learning: A meta-analysis of the empirical literature. Teachers College Record, 115(3), 1-47, URL: https://www.tcrecord.org/Content. asp?ContentId $=16882$.

Moskal, P., Dziuban, C., \& Hartman, J. (2013). Blended learning: A dangerous idea?. The Internet and Higher Education, 18, 15-23, DOI: https://doi. org/10.1016/j.iheduc.2012.12.001.

Norberg, A., Dziuban, C. D., \& Moskal, P. D. (2011). A time based blended learning model. On the Horizon, 19(3), 207-216, DOI: 10.1108/10748121111163913.

Padilla-MeléNdez, A., Del Aguila-Obra, A. R., \& Garrido-Moreno, A. (2013). Perceived playfulness, gender differences and technology acceptance model in a blended learning scenario. Computers \& Education, 63, 306-317, DOI: 10.1016/j.compedu.2012.12.014.

Sarofah, N. (2019). Model pembelajaran blended learning untuk meningkatkan kemandirian dan hasil belajar siswa Kelas X IPS 3 Kompetensi Dasar Koperasi dan Pengelolaan Koperasi di SMA Negeri Arjasa Jember. Skripsi tidak diterbitkan. Universitas Jember.

Sjukur, S. B. (2012). Pengaruh blended learning terhadap motivasi belajar dan hasil belajar siswa di tingkat SMK. Jurnal pendidikan vokasi, 2(3), 368-378, DOI: 
https://doi.org/10.21831/jpv.v2i3.1043.

So, H. J., \& Bonk, C. J. (2010). Examining the roles of blended learning approaches in computersupported collaborative learning (CSCL) environments: A Delphi study. Journal of Educational Technology \& Society, 13(3), 189-200, URL: https://www.learntechlib.org/p/74916/.

Staker, H., \& Horn, M. B. (2013). Blended Learning in the K12 Education Sector. Blended learning: Research perspectives, 2, 287-300. 